\title{
My committment to veganism as responsible consumption in reference to SDG 12
}

\author{
Jade Starr \\ Envigogika 13 (1) - Inspirations/ I nspirace \\ Published/ Publikováno 20. 8. 2018 \\ DOI : $\underline{10.14712 / 18023061.575}$
}

\begin{abstract}
This article examines the author's committment to veganism in the context of SDG 12 "Responsible Consumption and Production". Refering to the framework of education for sustainable development learning objectives outlined in the 2017 UNESCO publication, Education for Sustainable Development Goals: Learning Objectives (lead author Marco Rieckmann) the author relates her lifestyle choice to the three domains of learning objectives: cognitive, socio-emotional and behavioural.
\end{abstract}

\section{Key words}

Veganism; sustainability lifestyle choice; SDG 12 Responsible Consumption and Production; education for sustainable development goals; education for sustainable development competences.

\section{Abstrakt}

Autorka článku odhaluje svůj závazek k veganství, a to v souvislostech SDG 12 "Odpovědná spotřeba a výroba“. Volbu svého životního stylu rozebírá ve vztahu ke třem oblastem učení: kognitivní, sociálně-emocionální a behaviorální; tuto osobní zkušenost reflektuje ve struktuře kompetencí navržených pro vzdělávání k cíli SDG 12 v publikaci Vzdělávání pro cíle udržitelného rozvoje: cíle učení (UNESCO, 2017, vedoucí autor Marco Rieckmann).

\section{Klíčová slova}

Veganství; volba udržitelného životního stylu; SDG 12 Odpovědná spotřeba a výroba; vzdělávání pro cíle trvale udržitelného rozvoje; kompetence pro cíle udržitelného rozvoje. 
1. The learner understands how individual lifestyle choices influence social, economic and environmental development.

a. Systems thinking and self-awareness competencies

i. Understanding how my personal consumption habits may influence the world as well as the consumption habits of the people around me is a factor that contributed to my going vegan.

b. Anticipatory competency

i. My understanding of the future without an increase in sustainable consumption is not pleasant; it is important to not only think of the future in terms of my own lifetime but also generations to come.

ii. A sustainable future is the most desirable to me, but is not necessarily probable with current practices. I base my lifestyle off of what will hopefully contribute to making my desired future more probable

c. Critical thinking competency

i. The understanding that while society may not be entirely focused on sustainable consumption, this can change.

ii. While society may value consuming animal products, my values are animal rights and environmental sustainability which led me to go vegan.

2. The learner understands production and consumption patterns and value chains and the interrelatedness of production and consumption (supply and demand, toxics, $\mathrm{CO} 2$ emissions, waste generation, health, working conditions, poverty, etc. ).

a. Systems thinking competency

i. My personal consumption habits can influence the people around me to follow similar patterns of sustainable consumption, which can ultimately decrease the demand for unsustainable products which will in turn lower the supply and may even influence companies to produce more sustainable goods.

b. Strategic competency

i. By spreading awareness about sustainability and veganism, more people convert to this lifestyle which, as previously stated, can influence businesses to become more sustainable since there is more demand for that.

3. The learner knows roles, rights and duties of different actors in production and consumption (media and advertising, enterprises, municipalities, legislation, consumers, etc. ).

a. Same as above; My actions can influence those around me, which can have a ripple effect on the communities in which I am a part of and ultimately producers.

4. The learner knows about strategies and practices of sustainable production and consumption

a. Strategic competency

i. Throughout my experience as a vegan I have consistently learned new methods of sustainable consumption including purchasing fresh, locally grown fruits and vegetables, supporting local businesses as opposed to large corporations, composting food waste, etc.

5. The learner understands dilemmas/trade-offs related to and system changes necessary for achieving sustainable consumption and production 
a. Normative competency

i. As previously stated, my greatest values are animal rights and sustainability.

ii. In order to change my lifestyle, I had to give up a lot of things that I used to enjoy. However, this was entirely necessary because a sustainable future is more important to me than something I may want to consume now.

b. Self awareness competency

i. Considering my role in the communities of which I am a part, I determined that going vegan and spreading awareness about veganism was the right thing for me to do, even if it meant I had to give up some things.

ii. It was not easy to make this transition, but I had to follow my gut instinct telling me what I needed to do.

6. The learner is able to communicate the need for sustainable practices in production and consumption.

\section{a. Collaboration competency}

i. It is necessary for me to understand the needs and desires of others in order to promote vegan and sustainable lifestyles in a way that will cater to individuals.

ii. It is important to understand that my lifestyle may not be right for everyone, and that there are other ways people can consume more sustainably without going vegan.

7. The learner is able to encourage others to engage in sustainable practices in consumption and production

a. Same as above; I had to learn how to encourage others to practice sustainable consumption in ways that cater to the individual.

i. I feel as I have learned and grown I am able to, for the most part, promote sustainable or vegan lifestyles without turning people off to the idea completely.

b. Normative competency

i. I had to learn that my values and desires for a sustainable future may differ from the values and desires of others.

ii. I learned how to promote sustainability in ways that align with other peoples' values and desires for the future.

8. The learner is able to differentiate between needs and wants and to reflect on their own individual consumer behaviour in light of the needs of the natural world, other people, cultures and countries, and future generations.

a. Self awareness competency

i. This is something I need to work on. Although when it comes to food I tend to practice sustainable consumption, there are a lot of things I buy that I do not need. It is a personal goal to become more of a minimalist and focus more on the things I need as well as what I can do to help the world and other people get what they need.

9. The learner is able to envision sustainable lifestyles

a. Critical thinking competency

i. There is not just one way to practice sustainable consumption, so I had to research and implement the best lifestyle choices that align with my personal values. 
10. The learner is able to feel responsible for the environmental and social impacts of their own individual behaviour as a producer or consumer

a. Anticipatory competency

i. As previously stated, I can see how my personal lifestyle choices can impact the future, so I've modified my lifestyle in order to support the future most desirable to me because I feel a responsibility to do so.

b. Normative competency

i. Prior to going vegan, I had to reflect on the lifestyle I was living a the time and envision how my actions were affecting the people around me and the environment.

ii. Because I feel a responsibility to practice sustainable consumption and take care of the environment, going vegan was necessary and worth the things I had to give up.

11. Behavioral learning objectives

a. Integrated problem solving competency

i. Incorporating all the above competencies into my everyday life has helped me transition from constantly making a conscious effort to practice sustainable consumption to sustainable consumption just being part of my normal lifestyle.

ii. Because of this, I no longer have to decide to only eat plant based foods or purchase environmentally friendly products over conventional products. It comes naturally to me now.

\section{Reference}

- UNESCO. (2017). Education for Sustainable Development Goals: Learning Objectives. Paris: UNESCO. Division for Inclusion, Peace and Sustainable Development. Online http://unesdoc.unesco.org/images/0024/002474/247444e.pdf 